\title{
Holocene Treeline History and Climate Change Across Northern Eurasia
}

\author{
Glen M. MacDonald \\ Departments of Geography and Biology, UCLA, Los Angeles, California 90095-1524
}

Andrei A. Velichko, Constantine V. Kremenetski, Olga K. Borisova, Aleksandra A. Goleva, and Andrei A. Andreev Institute of Geography, Russian Academy of Science, Moscow, Russia 109017

Les C. Cwynar and Richard T. Riding

Department of Biology, University of New Brunswick, Fredericton, New Brunswick, Canada E3B 6E1

Steven L. Forman

Department of Earth and Environmental Sciences, University of Illinois at Chicago, Chicago, Illinois 60607-7059

Tom W. D. Edwards and Ramon Aravena

Department of Earth Sciences, University of Waterloo, Waterloo, Ontario, Canada N2L 3G1

Dan Hammarlund

Department of Quaternary Geology, Lund University, Tornav 13, S-223 63 Lund, Sweden

Julian M. Szeicz†

Department of Geography, Queen's University, Kingston, Ontario, Canada K7L 3N6

and

Valery N. Gattaulin

Research Institute for Marine Geology and Geophysics, Riga, Latvia LV-1226

Received March 9, 1999

$R$ adiocarbon-dated macrofossils are used to document H olocene treeline history across northern R ussia (including Siberia). Boreal forest development in this region commenced by $10,000 \mathrm{yr}$ B.P. Over most of Russia, forest advanced to or near the current arctic coastline between 9000 and $7000 \mathrm{yr}$ B.P. and retreated to its present position by between 4000 and 3000 yr B.P. Forest establishment and retreat was roughly synchronous across most of northern R ussia. Treeline advance on the Kola Peninsula, however, appears to have occurred later than in other regions. D uring the period of maximum forest extension, the mean J uly temperatures along the northern coastline of $R$ ussia may have been $2.5^{\circ}$ to $7.0^{\circ} \mathrm{C}$ warmer than modern. The development of forest and expansion of treeline likely reflects a number of complimentary environmental conditions, including heightened summer insola-

\footnotetext{
$\dagger$ Deceased.
}

tion, the demise of Eurasian ice sheets, reduced sea-ice cover, greater continentality with eustatically lower sea level, and extreme Arctic penetration of warm N orth Atlantic waters. The late Holocene retreat of Eurasian treeline coincides with declining summer insolation, cooling arctic waters, and neoglaciation. $\odot 2000$ University of Washington.

Key Words: treeline; climate change; Holocene; arctic; Russia; Siberia; macrofossils.

\section{INTRODUCTION}

The establishment of forests in northern Eurasia contributed to Holocene warming and climate change by lowering highlatitude albedo and influencing the summer position of the arctic front (Foley et al., 1994; TEMPO, 1996; Pielke and Vidale, 1995; Texier et al., 1998). The northern treeline in 
Eurasia is associated with the $10^{\circ}$ to $12^{\circ} \mathrm{C}$ July isotherm and should be sensitive to changes in summer temperature. Holocene temperature changes at the treeline zone might be influenced by a number of factors, including variations in insolation due to Milankovitch orbital forcing, paleogeographic changes associated with deglaciation and sea-level rise, inflow of warm North Atlantic waters into the Arctic, strengthened atmospheric westerlies, and decreased summer sea-ice in the adjacent Arctic Ocean. Climate model experiments suggest northern Eurasia is particularly sensitive to changes in glacial ice extent and sea-surface temperatures in the North Atlantic region (Overpeck et al., 1996; Mikolajewicz et al., 1997). Documenting the timing of establishment of high-latitude forest in northern Eurasia and subsequent changes in treeline is important for understanding the development of Holocene climate and the relative importance of different forcing factors affecting climate at high latitudes and beyond.

Pollen records from the Russian treeline are sparse (Khotinsky, 1984; Peterson, 1993; Texier et al., 1998). However, the occurrence of large numbers of ancient tree stumps on the tundra of northern Siberia has been known since the reports of A.F. Middendorf in the 1860 s. Radiocarbon dating of in situ macrofossils can provide a means of reconstructing forest development and treeline movement during the late Quaternary (Eronen and Huttunen, 1993; Kullman, 1995; Lavoie and Payette, 1996; Kremenetski et al., 1998). Scientists of the former Soviet Union have reported numerous radiocarbon dates from tree macrofossils from the treeline. These macrofossils are from scattered locales, and the dates from individual sites usually consist of a limited number of specimens (Kremenetski et al., 1998).

In this paper, we present new radiocarbon dates for tree macrofossils from north of the modern Russian treeline. Most of the samples were obtained by systematic sampling at four sites located along a longitudinal transect extending from the Kola Peninsula eastward to the Lena River Delta. We combine these new dates with previously published Russian data to reconstruct the Holocene establishment of northern boreal forest and the subsequent history of the Eurasian treeline. We then examine the climatic forcing factors that may have controlled the timing of forest establishment and treeline movement.

\section{METHODS}

Kremenetski et al. (1998) provided a compilation of published radiocarbon dates from 249 macrofossils of Larix spp. (larch), Picea obovata (Ledeb.) (spruce), and tree Betula spp. (birch) found north of the modern Russian treeline. To supplement and assess the Russian data, we collected, identified, and radiocarbon dated 57 macrofossils of Larix spp., Picea obovata, and Betula spp. from sites located from the lower Pechora River eastward to the lower Lena River (Fig. 1; Table 1). Most of the samples are wood which was identified to genus by comparing thin sections to modern reference material. We also include radiocarbon dates for an additional 21 samples of Pinus sylvestris L. (Scots pine) wood found north of the modern treeline on the Kola Peninsula (MacDonald et al., 2000).

We intensively sampled three sites (Fig. 1) for tree macrofossils to supplement the existing Russian data set and to determine if the general history of forest development inferred from the Russian dates is supported when reconstructed from carefully and intensively sampled individual sites. At the Pechora River $\left(67^{\circ} 58^{\prime} \mathrm{N}, 51^{\circ} 35^{\prime} \mathrm{E}\right)$, Taymyr Peninsula $\left(70^{\circ} 22^{\prime} \mathrm{N}\right.$, $\left.87^{\circ} 33^{\prime} \mathrm{E}\right)$, and Lena River $\left(71^{\circ} 52^{\prime} \mathrm{N}, 127^{\circ} 04^{\prime} \mathrm{E}\right)$ we conducted a series of radial transects $(<5 \mathrm{~km}$ in length) and collected stumps from the tundra surface, the littoral zones of small lakes, and surface deposits and sections along streams. The Taymyr site lies about $60 \mathrm{~km}$ northwest of the mapped treeline (based upon 1:500,000 Russian topographic maps and U.S. Tactical Pilotage Charts). One living krummholz, Larix sibirica (Ledeb.), was encountered in the transects. The Lena site lies just beyond the mapped treeline, and a number of small Larix dahurica (Trautv.) trees and krummholz were encountered at low elevations near the main channel of the river. The uplands, where collection efforts were concentrated, were completely devoid of living trees. No living trees were encountered in the Pechora study area, which lies approximately $75 \mathrm{~km}$ north of the mapped treeline. Samples have also been obtained from the Kola Peninsula, where searches were conducted in the shallow waters of small lakes. Two lakes in the birch foresttundra zone $\left(68^{\circ} 43^{\prime} \mathrm{N}, 35^{\circ} 19^{\prime} \mathrm{E}\right)$ provided a series of Pinus sylvestris samples from approximately $25 \mathrm{~km}$ north of the mapped limits of the species (MacDonald et al., 2000).

We avoided sites which may have contained macrofossils transported from more southerly regions. Many of the specimens were found in rooted position. We therefore conclude that radiocarbon dates from the macrofossils provide reliable evidence of the past presence of living trees. As a first approximation, we assume that the numbers of radiocarbon-dated tree macrofossils within 1000-yr age-classes are positively related to the relative density of trees during each 1000-yr period. Each date represents a sample of wood from a different tree and not multiple dates from an individual specimen. The samples for each local area come from a number of collecting sites. Many of our samples are surface finds on the tundra or from shallow lakes although some samples were found in peat exposures or lake-sediment cores. Thus, our sampling strategy should not be biased toward overrepresentation of a given time period.

\section{RESULTS}

The radiocarbon dates from the Kola, Pechora, Taymyr, and Lena sites (Table 1; Fig. 1) fall between 9000 and 3000 yr B.P. (All ages are reported as ${ }^{14} \mathrm{C}$ years before A.D. 1950). The samples from the Pechora and Taymyr sites contained both Larix and Picea. Only Larix wood was identified from the Lena River site. Only Pinus was reported from the Kola 
TABLE 1

Radiocarbon D ated Macrofossils of Trees from the Northern Treeline Zone of the R ussian Federation

Location

(N latitude; E longitude)

Material

Age yr B.P.

Age CAL

Lab no.

$70^{\circ} 59^{\prime}, 66^{\circ} 33^{\prime}$

$69^{\circ} 43^{\prime}, 66^{\circ} 50^{\prime}$

$69^{\circ} 13^{\prime}, 86^{\circ} 33^{\prime}$

$67^{\circ} 58^{\prime}, 51^{\circ} 35^{\prime}$

$70^{\circ} 22^{\prime}, 87^{\circ} 33^{\prime}$

$71^{\circ} 52^{\prime}, 127^{\circ} 04^{\prime}$

$71^{\circ} 30^{\prime}, 128^{\circ} 58^{\prime}$

$67^{\circ} 58^{\prime}, 51^{\circ} 34^{\prime}$

Betula (tree)

wood

bark

wood

bark

bark

wood

wood

wood

wood

wood

wood

wood

wood

wood

wood

wood

wood

wood

wood

wood

wood

wood

wood

wood

wood

wood

wood

wood

wood

wood

wood

wood

wood

wood

wood

wood

wood

wood

wood

wood

wood

wood

wood

wood

wood

wood

wood

wood

wood

wood

$$
\begin{aligned}
& 8780 \pm 150 \\
& 8610 \pm 150 \\
& 8020 \pm 80 \\
& 4010 \pm 70 \\
& 3980 \pm 70
\end{aligned}
$$

Larix

$5280 \pm 70$

$4815 \pm 83$

$8430 \pm 80$

$8260 \pm 70$

$8260 \pm 80$

$8240 \pm 90$

$7880 \pm 80$

$7680 \pm 80$

$7050 \pm 70$

$6100 \pm 80$

$6030 \pm 80$

$4610 \pm 70$

$3750 \pm 70$

$3530 \pm 70$

$7840 \pm 90$

$7014 \pm 65$

$6554 \pm 81$

$6517 \pm 88$

$6101 \pm 71$

$6030 \pm 80$

$5722 \pm 53$

$5220 \pm 80$

$4880 \pm 80$

$4614 \pm 59$

$4570 \pm 80$

$4549 \pm 69$

$4239 \pm 56$

$4220 \pm 70$

$4210 \pm 80$

$4200 \pm 70$

$7744 \pm 62$

\section{Picea}

$8460 \pm 70$

$8380 \pm 80$

$8080 \pm 70$

$7820 \pm 70$

$6740 \pm 70$

$6500 \pm 90$

$6050 \pm 80$

$5200 \pm 60$

$4130 \pm 70$

$4092 \pm 49$

$4080 \pm 70$

$3920 \pm 70$

$3880 \pm 70$

$3710 \pm 80$
9709

9524

8954

4492

4417

6079

5584

9436

9242

9242

9214

8578

8412

7860

6942

6878

5309

4089

3774

8556

7799

7393

7387

6943

6878

6490

5943

5605

5310

5295

5288

4830

4740

4743

4729

8468

9445

9414

8948

8550

7544

7384

6887

5935

4609

4561

4535

4361

4335

4029
GX-21799

GX-21801

IGAN-368

WAT-2754

WAT-2753

Beta- 84942

IGAS-1600

WAT-2726

WAT-2716

WAT-2727

WAT-2718

WAT-2723

WAT-2719

WAT-2725

WAT-2720

WAT-2729

WAT-2722

WAT-2721

WAT-2724

WAT-2850

IGAS-1525

IGAS-1520

IGAS-1522

IGAS-1515

WAT-2852

IGAS-1506

WAT-2849

WAT-2846

IGAS-1519

WAT-2851

IGAS-1524

IGAS-1518

WAT-2853

WAT-2854

WAT-2855

IGAS-1517

Beta-84944

Beta-84941

Beta-84940

Beta-84945

Beta-84947

Beta-84946

Beta-84948

Beta-84937

Beta-84936

IGAS-1604

Beta-84935

Beta-84939

Beta-84943

Beta-84938 
TABLE 1-Continued

Location

(N latitude; E longitude)

Material

Age yr B.P.

Age CAL

Lab no.

$$
\begin{aligned}
& 68^{\circ} 15^{\prime}, 68^{\circ} 10^{\prime} \\
& 69^{\circ} 13^{\prime}, 86^{\circ} 33^{\prime} \\
& 69^{\circ} 25^{\prime}, 86^{\circ} 39^{\prime}
\end{aligned}
$$

$70^{\circ} 22^{\prime}, 87^{\circ} 33^{\prime}$

$68^{\circ} 43^{\prime}, 35^{\circ} 19^{\prime}$

needles
cone
cone
cone
cone
cone
wood
wood

wood
wood
wood
wood
wood
wood
wood
wood
wood
wood
wood
wood
wood
wood
wood
wood
wood
wood
wood
wood
wood

$3770 \pm 70$

$6070 \pm 130$

$6000 \pm 130$

$8790 \pm 110$

$8750 \pm 130$

$8210 \pm 140$

$6520 \pm 70$

$6230 \pm 70$

Pinus
$6680 \pm 70$
$6600 \pm 60$
$6450 \pm 70$
$6440 \pm 80$
$6340 \pm 90$
$6330 \pm 80$
$6220 \pm 70$
$6150 \pm 70$
$6090 \pm 80$
$6050 \pm 60$
$6010 \pm 60$
$5800 \pm 70$
$5770 \pm 70$
$5530 \pm 90$
$5520 \pm 70$
$5070 \pm 80$
$4820 \pm 90$
$4640 \pm 90$
$4570 \pm 70$
$4500 \pm 80$
$3830 \pm 70$

4109
6895
6821
9704
9761
9123
7387
7105

TO-4744

WAT-2756

WAT-2755

WAT-2770

WAT-2764

WAT-2771

WAT-2728

WAT-2717
Beta-112747

Beta-112753

Beta-112743

Beta-112751

Beta-112763

Beta-112762

Beta-112744

Beta-112748

Beta-112754

Beta-112746

Beta-112745

Beta-112761

Beta-112765

Beta-112766

Beta-112764

Beta-112768

Beta-112759

Beta-112749

Beta-112757

Beta-112758

Beta-112750

Note. Radiocarbon dates (yr B.P.) and calibrated (Stuiver and Reimer, 1993) dates (CAL) before present for identified tree wood, bark, needles, and cones from sites at and beyond the modern northern treeline zone of the Russian Federation.

(MacDonald et al., 2000), and the oldest samples are relatively young $(<7000 \mathrm{yr}$ B.P.) as compared to sites from the other regions.

The span of 9000 to 3000 yr B.P. obtained from our sampling of Larix is less than the total time span of the previously published Russian dates, which range from 16,000 to $600 \mathrm{yr}$ B.P. However, the 9000 to 3000 yr B.P. interval corresponds with the period in which the vast majority of the Russian dates fall (Fig. 2). The previously published samples that are older than the ones described here may represent the occurrence of scattered trees captured in the larger and more geographically dispersed Russian data network. The most recent dates from the Russian data set come from sites that are at or just south of the present limits of Larix (Kremenetski et al., 1998).

The dates we obtained from Picea macrofossils correspond with the interval of 9000 to 4000 yr B.P. reported from the Russian data set (Fig. 2). The dates from Pinus sylvestris span a shorter range ( $\sim 6680$ to $3830 \mathrm{yr}$ B.P.) than any of the other tree taxa. However, the ages obtained from Kola Pinus corre- spond closely with the range of ages obtained from radiocarbon-dated Pinus samples from northern Fennoscandia (Eronen and Huttunen, 1993). Although we have recovered and dated fossils of Betula trees from peat sections (Table 1), we did not recover any during our systematic sampling of the four local sites. The Russian Betula samples are all found in peat and colluvial deposits (Kremenetski et al., 1998), and the wood is likely not preserved on the tundra surface or in the shallow lake sediments from which most of our samples come.

The new samples from the Kola, Pechora, and Taymyr regions provide a geographic extension of the published Russian data set (Kremenetski et al., 1998). The samples of Larix and Picea from the Pechora are the westernmost dated macrofossils of these genera. The samples of Picea from the Taymyr are the easternmost dated macrofossils available for that genus. No previously obtained dates are available from the Russian literature for Pinus wood on the Kola Peninsula.

We combined our data with the broader Russian data set to determine if there were longitudinal trends or differences in 

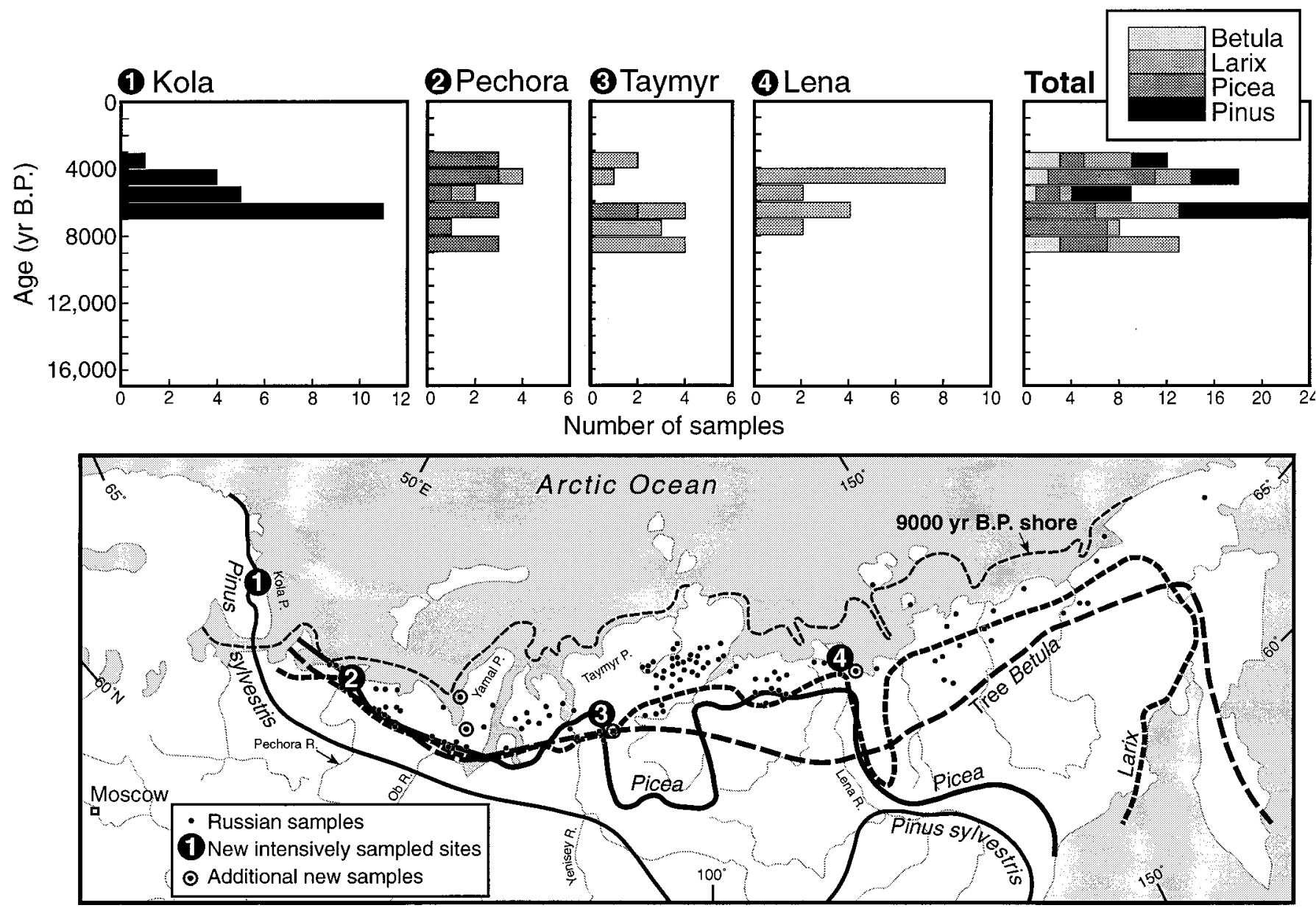

FIG. 1. The locations of the Kola Peninsula, Pechora River, Yamal Peninsula, Taymyr Peninsula, and Lena River regions where intensive local collecting of samples was conducted. The modern range limits of arboreal Betula, Larix, Picea, and Pinus are illustrated ("Tree and Shrub Distribution in the USSR," 1991). The present Larix treeline corresponds roughly with the $10^{\circ}$ to $12^{\circ} \mathrm{C}$ July isotherms ("Arctic Atlas," 1985). The histograms present the distribution of uncalibrated radiocarbon ages for Larix, Picea, and Pinus macrofossil wood recovered at the four sites (see Table 1).

treeline establishment and retreat (Fig. 3). We plotted the longitudinal distribution of the earliest late glacial and Holocene dates ( $>8000 \mathrm{yr}$ B.P.) and the most recent late Holocene dates $(<5000$ yr B.P.) in the combined data set. With the exception of the late expansion of Pinus on the northern Kola and an early expansion and possible retreat of tree Betula in far eastern Siberia, evidence for major longitudinal trends in far northern forest establishment or subsequent retreat appears to be absent. The combined data set (Fig. 3) indicates that the greatest number of dates for trees from north of the modern treeline falls between 9000 and 3000 yr B.P.

\section{TREELINE RECONSTRUCTION}

We can reconstruct the following general history of the northern Eurasian treeline based upon our new data and the previously published Russian data (Fig. 3). Betula trees were established in the far northeast by 11,000 to $10,000 \mathrm{yr}$ B.P. and were widely distributed beyond modern northern limits across Eurasia by 9000 to 8000 yr B.P. Given the modern distributions, Betula pubescens Ehrh. and Betula pendula (Roth.) were likely present at sites west of the Lena River. Sites east of the Lena River were probably occupied by Betula pendula. Based on macrofossil numbers, the greatest density of tree Betula perhaps occurred between 10,000 and $7000 \mathrm{yr}$ B.P. Betuladominated forest may have slightly preceded Larix- and Piceadominated forest in the early Holocene, and tree Betula density appears to have decreased following the increase in the conifers. The final decline of arboreal Betula north of the modern treeline occurred between 4000 and 3000 yr B.P.

Larix perhaps was present in low numbers in the far north as early as 16,000 yr B.P. (Fig. 3). The widespread expansion of Larix beyond the modern treeline occurred between 9000 and 8000 yr B.P. Based on the modern ranges, areas west of the 


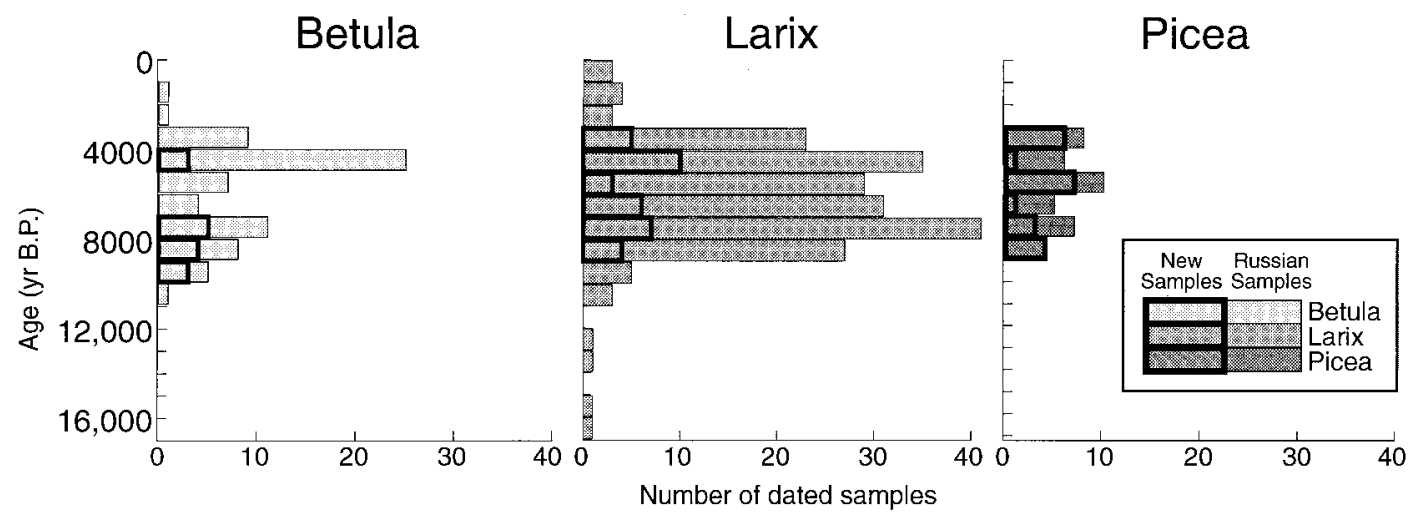

FIG. 2. Comparisons between the radiocarbon ages of macrofossils of Larix, Picea, and tree Betula from this study with previously published materials (Kremenetski et al., 1998).

Yenisey River were likely occupied by Larix sibirica, while sites to the east supported Larix dahurica. The density of Larix tree-cover north of the modern treeline was at a maximum between 8000 and 4000 yr B.P. (Fig. 3). Larix declined to its modern limits between 4000 and 3000 yr B.P.

Picea obovata is the only Picea species growing near the treeline in our study area. Consequently, Picea macrofossils recovered in this study are likely from this species. The expansion of Picea to sites north of the modern treeline occurred between 9000 and 8000 yr B.P. (Fig. 3). The retreat of Picea to its current limit and density at treeline occurred between 4000 and 3000 yr B.P.

The record from the Kola Peninsula indicates that Pinus sylvestris was present beyond its modern northern limits by $6680 \mathrm{yr}$ B.P. and persisted there until $3830 \mathrm{yr}$ B.P. The timing of the advance and retreat of treeline here is consistent with evidence from radiocarbon-dated wood found in adjacent northern Fennoscandinia. The advance of treeline in these northern regions appears to have occurred later than in more southern and central portions of Fennoscandia, where Pinus sylvestris wood has produced dates as old as $9000 \mathrm{yr}$ B.P. (Eronen and Huttunen, 1993; Kullman, 1995). The scarcity of dated Pinus remains suggests that the genus was never important north of the modern treeline in areas east of the Kola Peninsula.

Most of far northern Eurasia was forested by 9000 to 8000 yr B.P. (Fig. 3). The longitudinal distribution of tree genera at the treeline appears to have been roughly similar to today. However, macrofossils indicate that the early Holocene range of Larix sibirica south of the treeline extended as far west as the Scandes Mountains in Sweden (Kullman, 1998). The large number and size (some $>20 \mathrm{~cm}$ in diameter and $>2 \mathrm{~m}$ in length) of specimens recovered from northern Russia suggest that forest, or relatively well-treed forest-tundra, was present, rather than scattered krummholz. The decline of dated macrofossils from 4000 to $3000 \mathrm{yr}$ B.P. indicates that the present tundra vegetation was established during this time.

\section{DISCUSSION}

The modern conifer treeline of Eurasia (Fig. 3) corresponds roughly with the $10^{\circ}$ to $12^{\circ} \mathrm{C}$ July isotherms, while the tundra, where many of the stumps have been recovered, lies between this and the $7.5^{\circ}$ to $5.0^{\circ} \mathrm{C}$ July isotherms ("Arctic Atlas," 1985). This implies that over much of northern Eurasia summers may have been $2.5^{\circ}$ to $7.0^{\circ} \mathrm{C}$ warmer than today during the period $\sim 9000$ to $4000 \mathrm{yr}$ B.P. However, many other climatic factors may influence treeline (Stevens and Fox, 1991; Prentice et al., 1992). For example, adequate snow depth to protect young trees during the winter may play an important role in determining the northern limits of Picea in Scandinavia (Kullman and Engelmark, 1997).

The Holocene expansion of treeline likely reflects a number of environmental factors. The delay in development of extensive forest until $9000 \mathrm{yr}$ B.P. suggests a lag between increased summer insolation produced by Milankovitch orbital forcing and initiation of sustained warming of the treeline zone (Fig. 4). Assuming that factors such as seed dispersal, population growth rates, and soil conditions are not critical at the $1000-y r$ time-steps being considered here, this lag suggests that changes in boundary conditions due to Eurasian deglaciation, sea-level rise, and subsequent increase in advective heat transport from warm lower latitudes may have been additional factors influencing northern Eurasian climate and treeline. Scandinavian deglaciation enhanced the northward penetration of thermohaline circulation with sustained warming of the Norwegian, Greenland, and Barents seas starting at $\sim 9500$ yr B.P. (Salvigsen et al., 1992; Koç et al., 1993; Sarnthein et al., 1995; Bjorck et al., 1996; Jones, 1994). Deglaciation and sustained seasurface warming in the Norwegian and Barents seas would have enhanced heat transport into the Arctic. Evidence from marine diatoms, marine bivalve distributions, and lake sediment cores all indicate substantial warming of the North Atlantic and Norwegian/Greenland seas between 9000 and 4000 yr B.P. (Fig. 4). Cyclonic activity would have increased with 

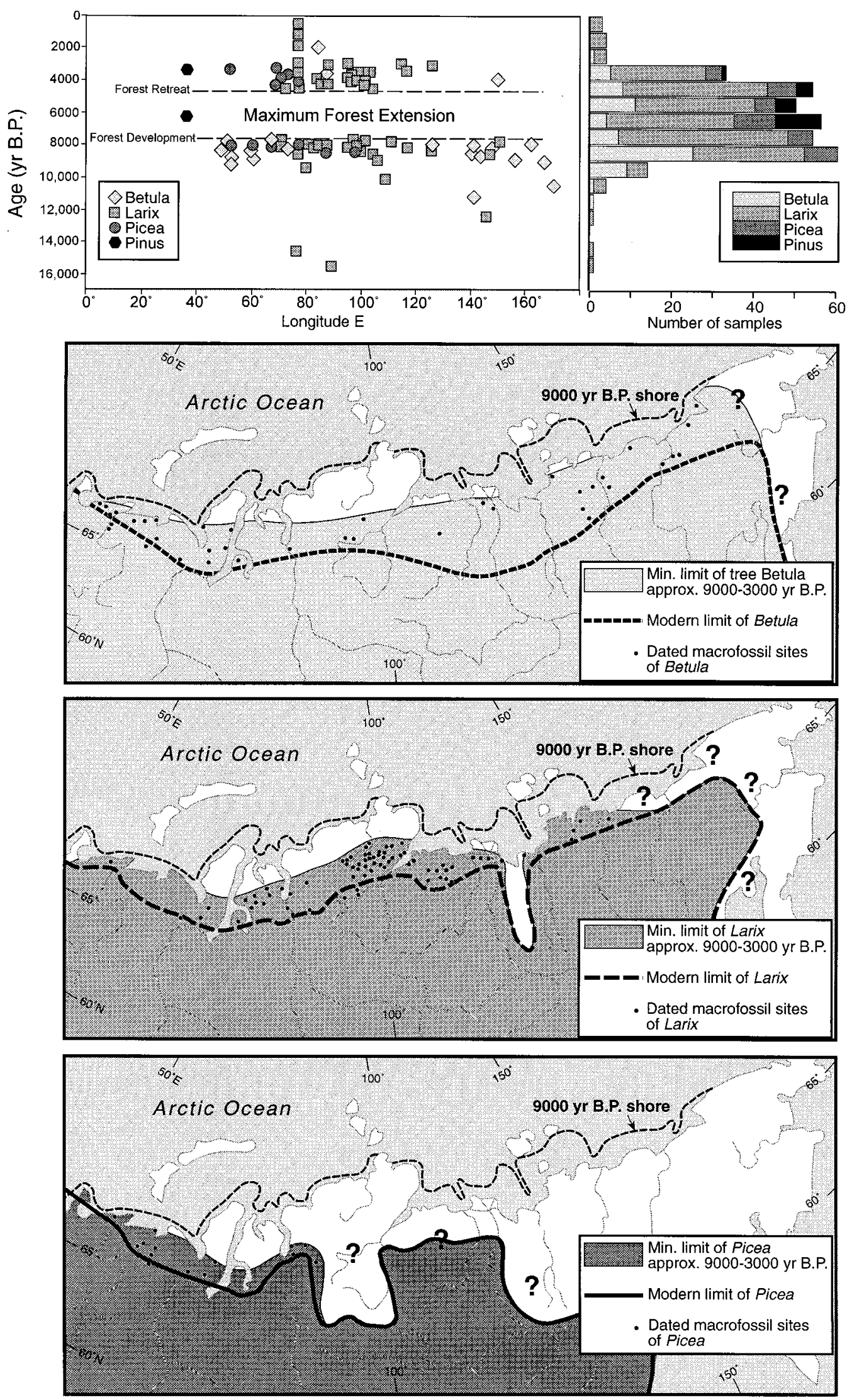


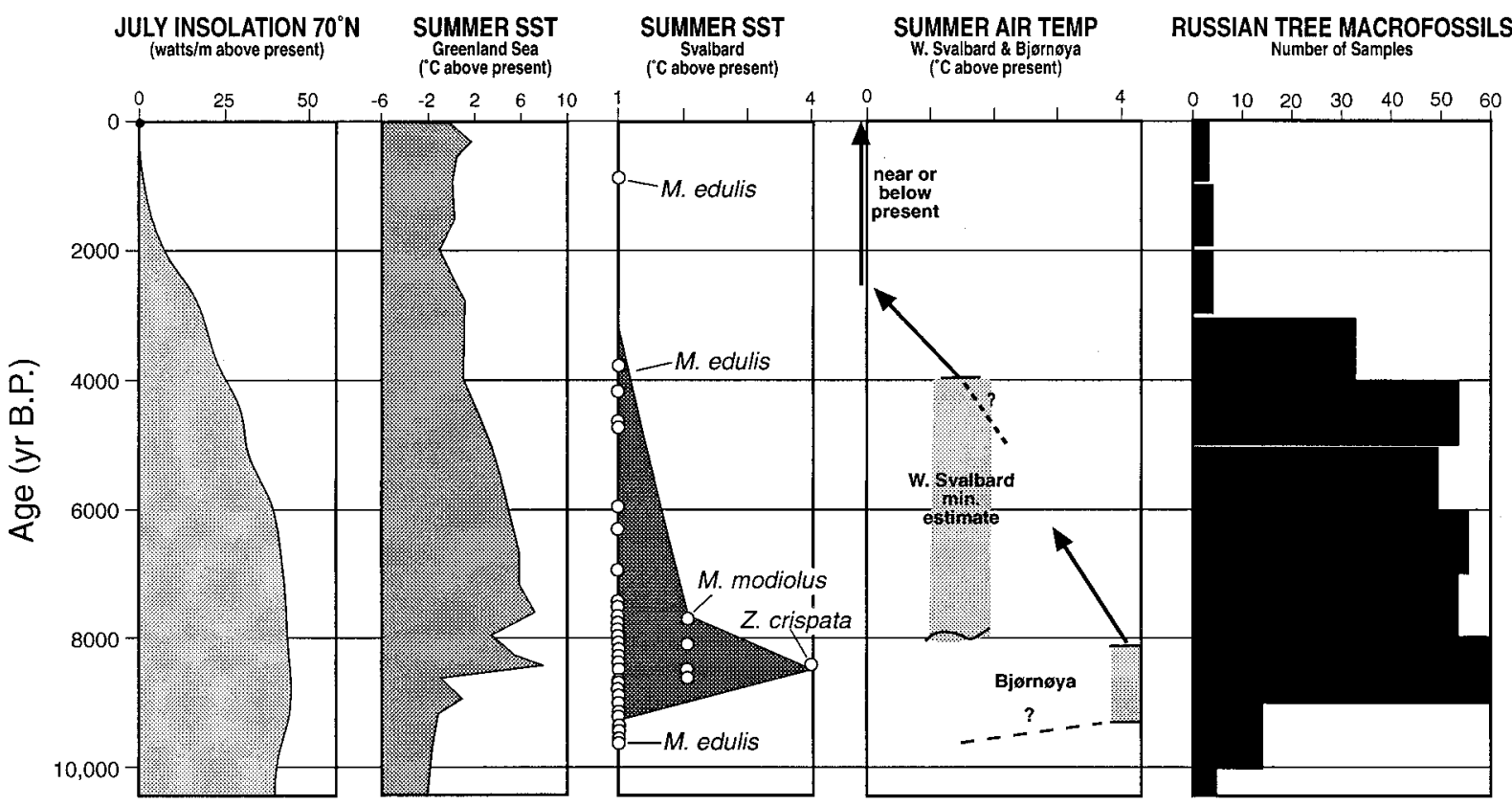

FIG . 4. July insolation at $70^{\circ} \mathrm{N}$ (Berger, 1978). Summer sea surface temperatures (SSTs) in the Greenland Sea reconstructed on the basis of diatoms (Koç et al., 1993). SSTs near Svalbard inferred from the occurrence of Mytilus edulis, M. modiolus, and Zirphaea shells (Salvigsen et al., 1992). Summer air temperatures for Svalbard and Bjørnøya reconstructed from plant macrofossil and paleolimnological records (Birks, 1991; Wolfarth et al., 1995). The chronological distribution of all tree macrofossils from the Russian treeline. All records are presented in uncalibrated radiocarbon years before present, and this imparts an uneven profile to the insolation curve due to variations in the relationship between radiocarbon years and calendar years (Stuiver and Riemer, 1993).

expansion of the Icelandic low into the Barents Sea, increasing the flow of warm and moist air into arctic Siberia (Rogers and Mosely-Thompson, 1995; Thompson and Wallace, 1998). Change in the Icelandic low would have its strongest impact on winter conditions in Eurasia. However, recent analyses of Arctic synoptic activity indicate that both winter and summer cyclone activity for the period A.D. 1952-1989 generally exhibit similar trends (Serreze et al., 1993). In addition, warmer winters leading to decreased sea-ice thickness, and earlier spring melting of ice and snow would have produced decreased albedo, increased growing season length, and enhanced early season sensible heat (Overpeck et al., 1996).

Recent climate model experiments suggest that Scandinavian deglaciation and warming of northern water masses could have caused the Eurasian treeline zone to warm by $6^{\circ}$ to $12^{\circ} \mathrm{C}$ (Overpeck et al., 1996; Fawcett et al., 1997; Mikolajewicz et al., 1997). However, the model experiments also suggest that the impact of this warming might have been most significant from the Taymyr Peninsula westward. Several factors perhaps influenced the eastward propagation of warming. The establishment of high latitude forests across western Eurasia would have decreased albedo and further enhanced warming to the east. The arctic coastline was located as much as $150 \mathrm{~km}$ north of its modern location at $9000 \mathrm{yr}$ B.P. due to globally depressed sea level (Fig. 3). This situation would have promoted warmer continental temperatures at sites which are today strongly influenced by the cold Arctic Ocean. The impact of this phenomenon would have been greatest east of the Taymyr Peninsula and near the lower $\mathrm{Ob}$ and Yenisey rivers. Finally, reduced sea-ice could have lowered albedo and increased oceanatmosphere heat and moisture exchange, thereby enhancing warming and moisture flux (Mitchell et al., 1988; Ganopolski et al., 1998).

The relatively late advance of Pinus sylvestris forest on the Kola Peninsula and in northern Fennoscandia remains problematic. Recent work combining stable isotope and palynological analyses of lake sediments suggests that the early Holocene climate of the region may have been con-

FIG. 3. The latitudinal pattern of boreal forest development and retreat across Russian Eurasia based upon the distribution of radiocarbon dated wood $>8000$ and $<5000 \mathrm{yr}$ B.P. from the data of this study combined with previously published dates. The maps provide the northern limits of tree genera between $\sim 8000$ and 3000 yr B.P. as evident from the macrofossil data. The inferred location of the arctic coastline of Eurasia at 9000 yr B.P., which approximates the present 25-m bathymetric contours, is also indicated. Placement of the shoreline is based on global records that indicate sea level was approximately $25 \mathrm{~m}$ lower than present at 9000 yr B.P. and reached modern levels by $6000 \mathrm{yr}$ B.P. (Fairbanks, 1989). Some indication of changes in the relative density of treeline forest as it developed, occupied its Holocene northern limits, and then retreated is provided by a histogram that combines the radiocarbon ages obtained from this study with previously published data. 
siderably more influenced by marine flow and was wetter than the mid-Holocene climate (Seppä and Hammarlund, in press). The late increase of Pinus might be explained by its preference for drier conditions (Seppä and Hammarlund, in press). The types of trees growing in the Scandes Mountains of Sweden during the early Holocene suggest that there may be no modern analogue for the climate of Fennoscandia and the adjacent Kola Peninsula (Kullman, 1998). MacDonald et al. (2000) pointed out that winter insolation was lower than present during the early Holocene and that the susceptibility of Pinus sylvestris to desiccation and root damage due to cold winters may have restricted the northward advance of the species in this region. Colder winters might have also benefited the deciduous conifer genus Larix, which had an early Holocene range that included southern Scandinavia (Kullman, 1998).

The retreat of treeline between 4000 and 3000 yr B.P. coincides with decreasing summer insolation, cooling of arctic waters, possible expansion of sea ice, and neoglaciation (Fig. 4). Declining summer insolation would have decreased solar energy and temperatures during the growing season at treeline (Kutzbach et al., 1993). Cooler surface waters in the Norwegian, Greenland, and Barents seas would promote cooler conditions in northern Eurasia. In turn, the summer persistence of sea ice would lead to cooler air temperatures. The southward progression of tundra would result in an increase in albedo and displacement of the arctic front, providing positive feedbacks that enhanced cooling (Foley et al., 1994; TEMPO, 1996; Ganopolski et al., 1998).

The history of treeline development and retreat reflects the sensitivity of the Eurasian Arctic to a variety of changes in boundary conditions from the North Atlantic eastward. Summer insolation was already high when the conclusion of Scandinavian deglaciation and a strengthening of the meanstate of the North Atlantic resulted in increased advective heat transport into the Arctic. A more northerly coastline coupled with decreased albedo due to forest establishment and reduced sea-ice cover may have helped propagate warming east of the Taymyr Peninsula. Although the precise importance of each of these factors remains to be resolved, the end result was the development of boreal forest north of its modern limits across most of Russian Eurasia between 9000 and 8000 yr B.P.

\section{ACKNOWLEDGMENTS}

We thank Patricia Anderson, Ray Bradley, Cary Mock, Robert Webb, Tom Webb III, Herb Wright Jr., and anonymous reviewers for comments on earlier versions of this paper. We also thank all of the Russian and Canadian fieldworkers who contributed their hard work and expertise to our efforts. This paper is dedicated to the memory of Julian Szeicz. The research was supported by a National Sciences and Engineering Research Council (Canada) Special Collaborative Grant and a National Science Foundation Grant (ATM
9632926). This paper is PACT Contribution Number 19 and PARCS Contribution Number 144.

\section{REFERENCES}

“Arctic Atlas" (1985). USSR Academy of Sciences, Leningrad. [In Russian]

Berger, A. (1978). Long-term variations of caloric insolation resulting from the earth's orbital elements. Quaternary Research 9, 139-167.

Birks, H. H. (1991). Holocene vegetational history and climatic change in west Spitzbergen-Plant macrofossils from Skardtjorna, an arctic lake. Holocene 1, 209-218.

Bjorck, S., Kromer, B., Johnsen, S., Bennike, O., Hammarlund, D., Lemdahl, G., Possnert, G., Rasmussen, T., Wohlfarth, B., Hammer, C., and Spurk, M. (1996). Synchronized terrestrial-atmospheric deglacial records around the North Atlantic. Science 274, 1155-1160.

Eronen, M., and Huttunen, P. (1993). Pine megafossils as indicators of Holocene climatic changes in Fennoscandia. In "Oscillations of the Alpine and Polar Tree Limits in the Holocene" (B. Frenzel, Ed.), pp. 29-40. European Science Foundation, Strasbourg.

Fairbanks, R. G. (1989). A 17,000 year glacio-eustatic sea level record: Influence of glacial melting rates on the Younger Dryas event and deep ocean circulation. Nature 342, 637-642.

Fawcett, P. J., Agustsdottir, A. M., Alley, R. B., and Shuman, C. A. (1997). The Younger Dryas termination and North Atlantic Deep Water formation: Insights from climate model simulations and Greenland ice cores. Paleoceanography 12, 23-38.

Foley, J. A., Kutzbach, J. E., Coe, M. T., and Levis, S. (1994). Effects of boreal forest vegetation on global climate. Nature 371, 52-54.

Ganopolski, A., Kubatzki, C., Claussen, M., Brovkin, V., and Petoukhov, V. (1998). The influence of vegetation-atmosphere-ocean interaction on climate during the Mid-Holocene. Science 280, 1916-1919.

Jones, G. (1994). Holocene climate and deep ocean circulation changes: Evidence from AMS radiocarbon dated Argentine Basin (SW Atlantic) mudwaves. Paleoceanography 9, 1001-1016.

Koç, N., Jansen, E., and Haflidason, H. (1993). Paleooceanographic reconstruction of surface ocean conditions in the Greenland, Iceland and Norwegian Seas through the last $14 \mathrm{ka}$ based on diatoms. Quaternary Science Reviews 12, 115-140.

Khotinsky, N. A. (1984). Holocene vegetation history. In "Late Quaternary Environments of the USSR" (A. A. Velichko, Ed.), pp. 179-200. University of Minnesota, Minneapolis.

Kremenetski, C. V., Sulerzhitsky, L. D., and Hantemirov, R. (1998). Holocene history of the northern range limits of some trees and shrubs in Russia. Arctic and Alpine Research 30, 317-333.

Kullman, L. (1995). Holocene tree-limit and climate history from the Scandes Mountains, Sweden. Ecology 76, 2490-2502.

Kullman, L. (1998). Paleoecological, biogeographical and paleoclimatological implications of early Holocene immigration of Larix sibirica Ledeb. into the Scandes Mountains, Sweden. Global Ecology and Biogeography Letters 7, 181-188.

Kullman, L., and Englemark, O. (1997). Neoglacial climate control of subarctic Picea abies stand dynamics and range limits in northern Sweden. Arctic and Alpine Research 29, 315-326.

Kutzbach, J. E., Guetter, P. J., Behling, P. J., and Selin, R. (1993). Simulated climatic changes: Results of the COHMAP climate-model experiments. In "Global Climates Since the Last Glacial Maximum" (H. E. Wright, Jr., J. E. Kutzbach, T. Webb, III, W. F. Ruddiman, F. A. Street-Perrott, and P. J. Bartlein, Eds.), pp. 24-93. University of Minnesota Press, Minneapolis.

Lavoie, C., and Payette, S. (1996). The long-term stability of the boreal forest limit in subarctic Quebec. Ecology 77, 1226-1233. 
MacDonald, G. M., Gervais, B. R., Snyder, J. A., Tarasov, G. A., and Borisova, O. K. (2000). Radiocarbon dated Pinus sylvestris L. wood from beyond treeline on the Kola Peninsula, Russia. The Holocene 10, 143-147.

Mikolajewicz, U., Crowley, T. J., Schiller, A., and Voss, R. (1997). Modelling teleconnections between the North Atlantic and North Pacific during the Younger Dryas. Nature 387, 384-387.

Mitchell, J. F. B., Grahame, N. S., and Needham, K. J. (1988). Climate simulations for 9000 years before present: Seasonal variations and effect of the Laurentide Ice Sheet. Journal of Geophysical Research 93, 8283-8303.

Overpeck, J., Anderson, D., Trumbore, S., and Prell, W. (1996). The southern Indian Monsoon over the last 18,000 years. Climate Dynamics 12, 21-225.

Peterson, G. M. (1993). Vegetational and climatic history of the western former Soviet Union. In "Global Climates Since the Last Glacial Maximum" (H. E. Wright, Jr., J. E. Kutzbach, T. Webb, III, W. F. Ruddiman, F. A. Street-Perrott, and P. J. Bartlein, Eds.), pp. 169-193. University of Minnesota Press, Minneapolis.

Pielke, R. A., and Vidale, P. L. (1995). The boreal forest and the polar front. Journal of Geophysical Research 100, 25,755-25,758.

Prentice, I. C., Cramer, W., Harrison, S. P., Leemans, R., Monserud, R. A., and Solomon, A. M. (1992). A global biome model based on plant physiology and dominance, soil properties and climate. Journal of Biogeography 19, $117-134$

Rogers, J. C., and Moseley-Thompson, E. (1995). Atlantic arctic cyclones and the mild Siberian winters of the 1980's. Geophysical Research Letters 22, 799-802.

Salvigsen, O., Forman, S. L., and Miller, G. H. (1992). Thermophilous molluscs on Svalbard during the Holocene and their paleoclimatic implications. Polar Research 11, 1-10.

Sarnthein, M., Winn, K., Jung, S. J. A., Duplessy, J. C., Labeyrie, L., Erlen- keuser, H., and Ganssen, G. (1995). Changes in east Atlantic deepwater circulation over the last 30,000 years: Eight time slice reconstructions. Paleoceanography 9, 209-267.

Seppä, H., and Hammarlund, D. (in press). Pollen-stratigraphical evidence of Holocene hydrological change in northern Fennoscandia supported by independent isotopic data. Journal of Paleolimnology.

Serreze, M. C., Box, J. E., Barry, R. G., and Walsh, J. E. (1993). Characteristics of Arctic synoptic activity, 1952-1989. Meterology and Atmospheric Physics 51, 147-164.

Stevens, G. C., and Fox, J. F. (1991). The causes of treeline. Annual Review of Ecology and Systematics 22, 177-191.

Stuiver, M., and Reimer, P. J. (1993). Extended ${ }^{14} \mathrm{C}$ database and revised Calib $3.0{ }^{14} \mathrm{C}$ age calibration program. Radiocarbon $35,215-230$.

TEMPO (1996). Feedbacks between climate and the boreal forest during the Holocene epoch. Global Biogeochemical Cycles 10, 727-736.

Texier, D., de Noblet, N., Harrison, S. P., Haxeltine, A., Jolly, D., Joussaume, S., Laarif, F., Prentice, I. C., and Tarasov, P. (1998). Quantifying the role of biosphere-atmosphere feedbacks in climate change: Coupled model simulations for 6000 years BP and comparison with paleodata for northern Eurasia and northern Africa. Climate Dynamics 13, 865-882.

Thompson, D. W. J., and Wallace, J. M. (1998). The Arctic Oscillation signature in the wintertime geopotential height and temperature fields. Geophysical Research Letters 25, 1297-1300.

"Tree and Shrub Distribution in the USSR" Vol. I (1991). Nauka, Leningrad. [In Russian]

Wohlfarth, B., Lemdahl, G., Olsson, S., Persson, T., Snowball, I., Ising, J., and Jones, V. (1995). Early Holocene environment on Bjornoya (Svalbard) inferred from multidisciplinary lake sediment studies. Polar Research 14, 253-275. 